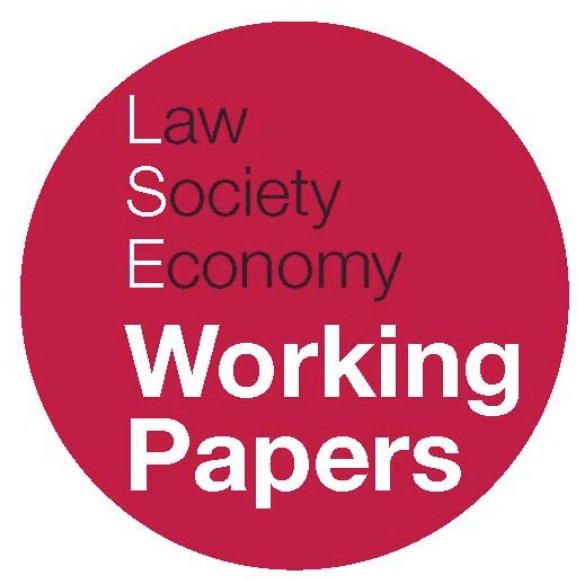

\title{
Global Administrative Law and the \\ Constitutional Ambition
}

\author{
Nico Krisch \\ LSE Law, Society and Economy Working Papers 10/2009 \\ London School of Economics and Political Science \\ Law Department
}

This paper can be downloaded without charge from LSE Law, Society and Economy Working Papers at: www.lse.ac.uk/collections/law/wps/wps.htm and the Social Sciences Research Network electronic library at: http://ssrn.com/abstract=1344788.

(C) Nico Krisch. Users may download and/or print one copy to facilitate their private study or for non-commercial research. Users may not engage in further distribution of this material or use it for any profit-making activities or any other form of commercial gain. 


\title{
Global Administrative Law and the Constitutional Ambition
}

\author{
Nico Krisch ${ }^{*}$
}

\begin{abstract}
The emergence of global governance has called into question many of the tools and concepts by which the traditionally dichotomous spaces of national and international politics and law were ordered, and various structuring proposals are competing to take their place. In this paper I examine two such proposals - global constitutionalism and global administrative law. Both represent distinct visions of how to approach the challenge, their key difference lying in their respective ambitions: constitutionalist visions set out to describe and develop a fully justified global order, while global administrative law is more limited in scope, focusing on particular elements of global governance and confining itself to the analysis and realisation of narrower political ideals, especially accountability. Such a limited approach raises serious problems, most prominently difficulties in separating 'administrative' from 'constitutional' issues and the risk of legitimising illegitimate institutions. But it also bears significant promise as it allows to focus on, and begin to answer, crucial questions of global governance without leaping to grand designs borrowed from dissimilar contexts and likely at odds with the fluid and diverse character of the postnational polity.
\end{abstract}

\section{INTRODUCTION}

As the political and the state have become ever more incongruent and public power has moved beyond national governments into a plurality of international and transnational sites, we are struggling to find the analytical and normative instruments to come to terms with the resulting new order. Countless structuring

\footnotetext{
* Hertie School of Governance, Berlin; formerly of the Law Department, London School of Economics and Political Science; email: krisch@hertie-school.org. I am grateful to Martin Loughlin, Euan MacDonald and Julia Black for comments on earlier drafts.
} 
proposals compete, leaving us with the sensation of a 'disorder of orders'1; in some ways, we do indeed seem to operate in a 'twilight' in which our vision has become blurred and orientation difficult. This twilight signals the demise of the state-centric, 'Westphalian' order that frames modern constitutional and political theory. But it is less clear which of our substantive political commitments we may be able (or want) to usher into the new daylight.

Some of the commitments in question are closely associated with key elements of domestic legal and political orders, and it is on two such elements I will focus: constitutionalism and administrative law. Both have sparked efforts at translation to the postnational or global levels, and they have increasingly come to be seen as competing approaches not only to the study, but also the construction, of the postnational space. I am unsure that 'competition' or talk of 'potential substitutes' (as the editors suggest) accurately describe the relationship of global constitutionalism and global administrative law; too different are the two projects in their scope and aims and too complementary could they eventually turn out to be. But there may indeed be good reason for pursuing one project rather than the other at this point: it is especially the type of project global administrative law represents - of a smaller scale, with a more modest reach - that might make it more suitable for academic study and political reform than constitutionalist approaches with their holistic vision.

The argument in this paper proceeds in four stages. After sketching the challenge both global constitutionalism and global administrative law face in the precarious legitimacy of transnational and global governance, I will examine more closely the scope and aims of both projects. It is in their respective ambitions that the key difference between the two lies: constitutionalist visions set out to describe and develop a fully justified global order, while global administrative law approaches are more limited in scope, focusing on particular elements of global governance and confining themselves to the analysis and realisation of narrower political ideals, especially accountability. Such a limited approach does, however, raise serious problems, both on the practical and the normative level. I focus here only on two sets of issues: the difficulty in separating 'administrative' from 'constitutional' issues and the risk of legitimising illegitimate institutions, in part by elevating them to the level of law. Although the resulting challenge for global administrative law is serious and will condition the further trajectory of the project, it should not distract from the significant advantages its more limited ambition entails.

\footnotetext{
1 N. Walker, 'Beyond boundary disputes and basic grids: Mapping the global disorder of normative orders' (2008) 6 International Journal of Constitutional Law 373.
} 


\section{THE PRECARIOUS LEGITIMACY OF GLOBAL GOVERNANCE}

Both global constitutionalism and global administrative law are, in their different ways, attempts at tackling the perceived legitimacy deficit of global governance. With the relocation of public power to the global level, legitimacy standards for transnational institutions have come to approximate more closely those we apply to domestic governments, and seen in this light, most transnational institutions fail badly - be it the UN Security Council with its unrepresentative membership and secretive decision-making, the World Bank with its unfairly weighted voting, or the Codex Alimentarius Commission with its skewed procedures for reaching decisions. None of them seems to satisfy democratic principles even remotely, legality appears as at most a weak factor in decision-making, and rights play only a marginal role. Yet some argue that the full application of domestic standards of legitimacy is mistaken, or at best premature, as the problems raised by global institutions are of a different kind to those we face in domestic politics and that they can largely be addressed through the channels of domestic constitutional orders, thus obviating (or at least alleviating) the need to develop new global frameworks. ${ }^{2}$ Before assessing the respective potentials of global constitutionalism and global administrative law, we should therefore gain a clearer picture of the extent and form of the challenge global governance presents.

\section{DOMESTIC CONSTITUTIONALISM AND ITS LIMITS}

The classical way of legitimising international institutions is based on the delegatory relationship with member states: the powers of these institutions derive from member states through their constitutive treaties; they are accountable to member states through the central representative body within the institution; and member states can control the ultimate effect of institutional decisions through domestic implementation. In this picture, the legitimacy concerns outlined above are of little weight, since whatever substantive problems international institutions raise will be dealt with through the channel of member states, and the central site for controlling transnational governance would be domestic constitutional settings. ${ }^{3}$

However, constructing the accountability of global governance around delegation and control - and thus addressing legitimacy issues through the prism of domestic constitutionalism - bears only limited promise. This is, first, because the initial delegation of powers is usually very thin: the founding treaties of international institutions generally contain only vague guidance as regards the

\footnotetext{
2 A. Moravcsik, 'Is there a 'Democratic Deficit' in World Politics? A Framework for Analysis' (2004) 39 Government \& Opposition 336.

3 In this vein, e.g., E. Schmidt-Aßmann, 'Die Herausforderung der Verwaltungsrechtswissenschaft durch die Internationalisierung der Verwaltungsbeziehungen' (2006) 45 Der Staat 315 (English: 'The Internationalization of Administrative Relations as a Challenge for Administrative Law Scholarship' (2008) 9 German Law Journal 2061).
} 
scope of powers, especially informal powers ${ }^{4}$, and even this limited determination disappears when it comes to transnational government networks which typically operate without a formal basis altogether. ${ }^{5}$ Moreover, delegation is entirely absent as regards outsiders (non-members) that may be affected by decisions ${ }^{6}$, or in the case of private regulators. The latter do not depend on any form of delegation but, even when they cooperate with governments, are typically self-appointed. ${ }^{7}$ Because of the need for flexibility in those institutions and the difficulty of creating and speedily adapting treaty mandates, more extensive formal bases and greater specificity will usually be hard to achieve.

Moreover, the level of control each member state can exercise over an international institution will usually be very low. This is in part because of the problem of multiple, diverse principals: delegation structures are relatively unproblematic and may allow for meaningful degrees of control and accountability if there is only one principal (or few principals), as is typically the case in domestic settings where central governments or parliaments delegate power to lower levels or independent institutions. The situation becomes more problematic when the number of principals increases: each of them can then retain only a smaller fraction of control, and mechanisms for holding agents to account become more cumbersome. ${ }^{8}$ Greater control would only flow from veto rights, but these would risk stalemate in any institutions with a significant number of members.

A more promising avenue for domestic control might then be the implementation of international decisions. Whether binding or non-binding, most norms and decisions in global governance depend on domestic implementation for their actual effectiveness; global regulatory action is typically not followed by its ultimate addressees (state officials, individuals, companies) unless it becomes part of the domestic legal and regulatory framework. In the classical vision of international law, this opens up space for states' sovereign choices as to their domestic policies - even if such choices contradict international rules, they remain decisive in the domestic realm (even though they might entail responsibility on the international level). This in turn allows domestic constitutionalism to take centre stage, by determining when and how international norms can enter domestic law,

\footnotetext{
${ }^{4}$ For example, the OECD's founding treaty defines as the organisation's main goal 'to promote policies ... to achieve the highest sustainable economic growth and employment and a rising standard of living in Member countries'; and the OECD's organs are granted the power 'to take decisions ... [and] make recommendations' 'to achieve its aims'; see Articles 1 and 5 OECD Convention. On the additional uncertainties surrounding the interpretation of powers of international institutions, see J. Klabbers, $A n$ Introduction to International Institutional Law (Cambridge: Cambridge University Press, 2002) 60-81.

${ }^{5}$ See A.-M. Slaughter, $A$ New World Order (Princeton: Princeton University Press, 2004).

${ }^{6}$ The Basel Committee for Banking Supervision, for example, consists of only eleven members but its decisions are designed to apply far beyond this circle; see M.S. Barr \& G.P. Miller, 'Global Administrative Law: The View from Basel' (2006) 17 European Journal of International Law 15, 39-41.

7 On the example of forestry regulation, see E. Meidinger, 'The Administrative Law of Global PrivatePublic Regulation: The Case of Forestry' (2006) 17 European Journal of International Law 47.

8 On international institutions, see A.P. Cortell \& S. Peterson, 'Dutiful agents, rogue actors, or both? Staffing, voting, rules and slack in the WHO and WTO', in D.G. Hawkins et al. (eds.), Delegation and Agency in International Organizations (Cambridge: Cambridge University Press, 2006) 255; D.A. Lake \& M.D. McCubbins, 'The logic of delegation to international organizations', ibid, 341, 361-367.
} 
and by definining the define substantive limits and procedural conditions for the engagement with the international sphere. ${ }^{9}$ However, for this to be an effective tool of national control, it has to operate in a relatively permissive environment: if non-implementation is to remain a real (rather than merely formal) option, it must not be overly costly. In classical international law, this was certainly the case, as non-compliance even with binding rules was rarely subject to meaningful sanctions. Yet today, enforcement has gained teeth in many areas of global governance. If refusing compliance with WTO rules exposes a country to trade sanctions that cost millions, sometimes hundreds of millions, of dollars, it presents a conceivable option for only very few actors. ${ }^{10}$ Well beyond that, where international standards help solve coordination games in global markets, opting out is often not a real option as it entails exclusion from those markets, or at least significant hurdles for access. ${ }^{11}$ Non-compliance - even with non-binding instruments - thus often comes at a prohibitive cost, and the prospect of domestic constitutionalism retaining control through implementation is accordingly limited. This problem is exacerbated when global decision-making involves domestic regulators directly: if they are implicated in the setting of global standards (as they typically are in government networks), their commitment to compliance will often be too strong to allow for much flexibility at the implementation stage. ${ }^{12}$

Thus neither the delegatory relationship nor domestic implementation can guarantee significant national control over global governance institutions beyond the stage of their creation. This significantly conditions the viability of the domestic constitutional route: except for particularly powerful states, or in contexts in which the costs of non-compliance are low, the prospect of domestic constitutionalism shaping global governance or controlling its impact will be limited.

\section{LEGITIMACY, INCLUSIVENESS, EFFECTIVENESS}

If the domestic constitutional route thus offers little help in alleviating the legitimacy problems of global governance, it might still be asked whether those problems are really as grave as they at first sight appear. Rather than seeing global governance as a threat to democracy and self-government, it might be regarded as strengthening them: strengthening them, that is, by readjusting the boundaries of

\footnotetext{
9 This is certainly the ambition of some constitutional courts; see, e.g., Bundesverfassungsgericht, Judgments of 12 October 1993, Maastricht, BVerfGE 89, 155; 14 October 2004, Görgülü, BVerfGE 111, 307. See also M. Kumm, 'Constitutional Democracy Encounters International Law: Terms of Engagement', in S. Choudhry, The Migration of Constitutional Ideas (Cambridge: Cambridge University Press, 2007) 256.

10 See, for example, the EC-Beef Hormones case in the WTO and the ensuing sanctions; M. Böckenförde, 'Hormone Ban in Dispute Again' (2008) 12 ASIL Insight no. 25.

11 On the structure of coordination games in international standardisation, see. S.D. Krasner, 'Global Communications and National Power: Life on the Pareto Frontier' (1991) 43 World Politics 336.

12 See R.B. Stewart, 'The Global Regulatory Challenge to U.S. Administrative Law' (2005) 37 NYU Journal of International Law and Politics 695, 699-712, also on steps to nevertheless strengthen domestic accountability processes. On the latter, see also A.-M. Slaughter, 'Disaggregated Sovereignty: Towards the Public Accountability of Global Government Networks' (2004) 39 Government \& Opposition 159, 171-4.
} 
the polity in a more inclusive way and by reestablishing some of the effectiveness domestic democracies have lost in the process of globalisation.

This point is based on the lack of congruence of nation-state boundaries with the range of those affected by political decisions. In an interdependent world, political challenges as well as regulatory responses straddle national boundaries in any number of areas. Consequently, leaving ultimate responsibility to national polities effectively disenfranchises outsiders that are significantly affected by decisions. ${ }^{13}$ Expanding the scope of the polity and moving political decisions up to transnational and international levels may then be seen as a response to the legitimacy deficits that stem from the underinclusiveness of the state-based, 'Westphalian' order.

Creating structures of global governance can also be perceived as a gain rather than as a loss from the perspective of the national constituency. As domestic governments have become unable to tackle central challenges - from environmental problems to tax evasion - alone, transnational regulatory institutions have become central to reestablishing the problem-solving capacity of public actors. Insofar as democracy depends on effective institutions, adjusting decision-making structures to the scope of the problems becomes itself a democratic demand. ${ }^{14}$

Although this may alleviate the legitimacy problems of global governance, it will certainly not entirely remove them. For those arguments only carry weight if decision-making beyond the state can indeed be seen as an exercise of democracy - if it can be understood as sufficiently linked to individual and collective selfgovernment. The actual provision of public or collective goods will hardly ever serve to entirely remove questions of input legitimacy from view: even if everybody receives benefits from an institution, some typically gain more and some less; distributional conflict remains ubiquitous. ${ }^{15}$ And even if it is true that decisions of a technical character trigger weaker demands for input legitimacy than those involving redistributive measures, domestic political practices still require them to be embedded in a democratically-controlled framework that defines what counts as a public good and is, if necessary, able to adjust that determination. ${ }^{16}$ Democracy may not be the only source of legitimacy for public power, but other sources are likely to serve as complements, not substitutes for it. ${ }^{17}$

However, even if we accept this point in principle, the degree of input legitimacy we require on the global level may still differ from that we typically ask

\footnotetext{
13 See, e.g., D. Held, Democracy and the Global Order (Cambridge: Polity Press, 1995) ch. 10; I.M. Young, Inclusion and Democracy (Oxford: Oxford University Press, 2000) ch. 7.

${ }^{14}$ E.g., Held, ibid, ch. 11.

15 See, e.g., Krasner, n 11 above.

16 See F. Scharpf, 'Legitimationskonzepte jenseits des Nationalstaats', MPIfG Working Paper 04/6 (http://www.mpifg.de/pu/workpap/wp04-6/wp04-6.html) sections 2 and 3; E. Schmidt-Assmann, Das Allgemeine Verwaltungsrecht als Ordnungsidee (Heidelberg, New York: Springer, 2nd ed, 2004) 259-261.

17 However, in a sociological rather than normative account, one may find those different sources (which may also be more variegated than the input/output dichotomy suggests) to compete; see J. Black, 'Constructing and contesting legitimacy and accountability in polycentric regulatory regimes' (2008) Regulation \& Governance 137, 145-146.
} 
for domestically. ${ }^{18}$ In the national framework, the tension between the provision of substantive goods and democratic procedures is usually limited, simply because it operates in the shadow of relatively strong public problem-solving capacity through state institutions. ${ }^{19}$ On the global level, though, this tension is more pronounced, and if we demand a high level of procedural integrity, we may have to sacrifice substantive benefits to a much larger extent. This becomes evident in Jürgen Habermas's vision of global politics: because of his insistence on strong democracy, he generally restricts political integration to the regional level (where strong democracy may be possible) and conceives of global politics only in classical international (inter-regional) terms. ${ }^{20}$ This may, however, lead to severe costs in the provision of global public goods and we may ask whether his approach (just as most modern political theory since the rise of the absolutist state) is not based too much on a preoccupation with limiting public power to invite translation to the postnational environment. If we take a more Hobbesian, or possibly also republican, perspective instead, we may place stronger emphasis on unleashing public power and will perhaps rebalance the weight of substantive outcomes and procedural integrity for the global level. Whether this should go as far as Fritz Scharpf's suggestion that pareto-optimal solutions may be legitimised by output considerations alone ${ }^{21}$ is doubtful - too contested will be the qualification as pareto-optimal itself, and too strong the conflict over the distribution of gains even if all actors are (absolutely) better off. But one might still accept that the gains in the provision of public goods by (input-deficient) international institutions compared to an absence of such institutions (and the consequent retreat of public power to the national realm) may to some extent legitimise their operation.

\section{THE CONSTITUTIONALIST AMBITION}

In spite of the caveats above, the general legitimacy problem in global governance remains: domestic constitutionalism does not usually provide an effective remedy, and the greater inclusiveness and effectiveness that may come with global decision-making can help legitimise global governance only to a modest extent. Given the size of the challenge, it must thus appear tempting to undertake a largescale remaking of the current order of global governance, one that would go beyond the current institutional structure and refound it in a manner more closely

\footnotetext{
18 This may also hold for the type of input legitimacy: democratic governance may follow other than the electoral patterns characteristic of the domestic context. I cannot pursue this here; see T. Macdonald \& K. Macdonald, 'Non-Electoral Accountability in Global Politics: Strengthening Democratic Control within the Global Garment Industry' (2006) 17 European Journal of International Law 89; J. Bohman, Democracy across Borders (Cambridge, Mass.: MIT Press, 2007).

${ }^{19}$ See Scharpf, n 16 above, section 3.

${ }^{20}$ J. Habermas, Die postnationale Konstellation (Frankfurt/Main: Suhrkamp, 1998) ch. 4; Der gespaltene Westen (Frankfurt/Main: Suhrkamp, 2004) ch. 8.

21 Scharpf, $n 16$ above, section 4.
} 
aligned with domestic political ideals. It is thus not surprising that over the last decade calls not only for a democratisation but also a full-scale 'constitutionalisation' of international affairs (and international law) have gained currency; constitutionalism today appears to many to be the yardstick against which the current order and proposals for its reform ought to be measured.

\section{VISIONS OF GLOBAL CONSTITUTIONALISM}

What precisely 'constitutionalism' in the global context means remains disputed; the debate has produced a great number of different 'constitutionalisms', ranging from emphases on human rights and judicial review in international institutions to broader calls for a legalisation of postnational politics and visions of a global order subject to an identifiable constitutional document. ${ }^{22}$ Here I will focus on a particular set of constitutionalist visions, 'foundational' ones, that provide the closest link with key domestic traditions. Other proposals, especially those focusing on legalisation, rights and review, evoke the domestic tradition of 'powerlimiting' constitutionalism that has been increasingly overshadowed by foundational approaches in the $20^{\text {th }}$ century and does not generate a comparable normative appeal either - whether they are adequately categorised as 'constitutionalist' is thus subject to doubt. ${ }^{23}$

Foundational constitutionalism, on the other hand, connects to the constitutional tradition spurred by the American and French revolutions, a tradition that places particular emphasis on the idea of a constitution as 'founding' and comprehensively organising the public power existing in a polity. A constitution in that sense - typically but not necessarily contained in a written document - represents a tool not only to establish limits to public institutions but also to realise self-government by defining the extent and procedural rules for the exercise of (delegated) governmental powers. Outside that framework, public power can no longer be legitimately exercised; all such power has to be traceable to the original 'pouvoir constituant' via the constitution. ${ }^{24}$

It is not difficult to see the appeal of this vision and why it would also be attractive on the postnational level. After all, it is a structure by which a polity can make a comprehensive claim to agency and wrestle its affairs back from the forces of chance, history and power. And it is a structure in which central pillars of

\footnotetext{
22 See only N. Walker, 'Taking Constitutionalism Beyond the State' (2008) 56 Political Studies 519; B. Fassbender, "We the Peoples of the United Nations": Constituent Power and Constitutional Form in International Law', in M. Loughlin \& N. Walker (eds), The Paradox of Constitutionalism: Constituent Power and Constitutional Form (Oxford: Oxford University Press, 2007) 269.

23 See in greater detail N. Krisch, 'Postnational Constitutionalism?', Discussion Draft (2008), at www.iilj.org/courses/documents/Krisch.IdeaofConstitutionalism.pdf. It should be noted that in the current debate there is no watertight distinction between the two strands; many approaches incorporate elements of both. I focus here on the ideal type of a foundational approach and those contributions to the literature that approximate it most closely. I am grateful to Euan MacDonald for urging me to clarify this point.

24 See C. Möllers, 'Verfassunggebende Gewalt - Verfassung - Konstitutionalisierung', in A. v. Bogdandy (ed), Europäisches Verfassungsrecht (Berlin, Heidelberg, New York: Springer, 2003) 1, 3-18.
} 
modern political thought - the rule of law, individual rights and collective selfgovernment - are brought together. ${ }^{25}$ Unsurprisingly then, efforts to draw on it for the postnational level have become increasingly widespread. The most tangible political result has been the European draft constitutional treaty, which appeared as an opportunity to place the European Union on a new foundation and open up new legitimacy resources. On the global level, the United Nations Charter has been reinterpreted as a constitutional document, towering above and framing other regimes of global governance as well as individual states. ${ }^{26}$

More broadly, such a tendency is visible in the many approaches that seek to give the current, largely unstructured, historically accidental and power-driven order of global governance a rational, justifiable shape in which the powers of institutions and their relationships with one another are clearly delimited. A good example is David Held's quasi-federal vision of the global order. ${ }^{27}$ Starting from the principle of 'equivalence' of decision-makers and decision-takers, Held envisages a political structure in which all those affected by a particular issue have a right to participate in decisions on it. Thus striving for inclusiveness while at the same time seeking to respect subsidiarity - locating decision-making as close to the individual as possible - the institutions he seeks to construct at the different levels of the global polity are to be assigned powers on issues for which decision-making at a lower level would be insufficient. Some issues, such as education or housing, would thus remain at the national or subnational level while others, like environmental problems with transboundary effect, would be dealt with on the regional or global level. To be sure, he acknowledges that the distribution of powers will - as in many national contexts - often be contested and complex to resolve, but in his view, a resolution in a public setting based on an overarching principle is preferable to leaving them 'to powerful geopolitical interests (dominant states) or market based organizations to resolve them alone'. ${ }^{28}$

\section{THE HOLISTIC AMBITION AND ITS PROBLEMS}

In good constitutionalist fashion, such a principled construction of the global institutional order is thus regarded as reason's antidote to the mere forces of history. Connecting in this way to domestic, foundational constitutionalism means adopting a holistic ambition, an ambition to construct a comprehensive, justified political order, and therein lies its appeal but also the source of serious problems.

\footnotetext{
25 Of course, foundational constitutionalism has never escaped critique, most notably for the limitations comprehensive constitutions impose on the realisation of the will of the people, and for the tendencies of juridification they engender. But it has proved attractive enough to become quasi-universal as a precondition for domestic governmental legitimacy.

26 B. Fassbender, 'The United Nations Charter as Constitution of the International Community' (1998) 36 Columbia Journal of Transnational Law 529.

27 Held, n 13 above. For other examples, see, e.g., Young, n 13 above; M. Kumm, 'The Legitimacy of International Law: A Constitutionalist Framework of Analysis' (2004) 15 European Journal of International Law 907.

28 D. Held, 'Democratic Accountability and Political Effectiveness from a Cosmopolitan Perspective' (2004) 39 Government \& Opposition 364, 382.
} 
Many of these problems are connected to the fact that such a comprehensive reconstruction would not only require massive institutional change but also a transformation of the societal basis on which the global order rests. ${ }^{29}$ To use an example already mentioned above, Jürgen Habermas - a protagonist of foundational constitutionalism in the European context - refrains from extending such a vision to the global level as it would stand in tension with the social fragmentation of the global polity: in his view the discursive conditions that ground democracy (ideally) in the nation-state, and might do so in certain areas of strong regional integration, are largely absent in the global realm. ${ }^{30}$

Yet the problems of the holistic approach go farther in a polity that is, more than even the most multicultural domestic settings, characterised by strong perhaps radical - social and cultural diversity. Already on the national plane, it has been questioned whether foundational constitutionalism is a fitting vision for diverse societies in which consensus is elusive even on the most basic, procedural level. In particular, the claim to found the political system on impartial rules that guide and circumscribe everyday political contestation has been critiqued as concealing the contested nature of fundamental issues and as legitimising the dominance of particular social positions (and the groups behind them) over others. ${ }^{31}$ The more diverse and contested the social space is, the less attractive seems the idea of freezing the political order in a seemingly neutral consensus, and the more appealing the recourse to either punctual, contractual settlements between groups or to institutional provisions that keep fundamental issues open to continuing contestation and revision.

This problem becomes particularly accentuated in the global context in which there is no agreement on the scope of the ultimately decisive polity, or on any form of hierarchy between different levels of the global polity - subnational, national, regional or global. All those different levels are beset by legitimacy problems that hamper claims to supremacy over the others: the global polity cannot institute any form of thick, democratic procedures of participation to ground its decisions, but regional, national or subnational levels also face legitimacy deficits because of their underinclusiveness: on issues that significantly affect outsiders, their claim to decision-making can always only be limited, provisional. $^{32}$ In such circumstances, the comprehensive determination of decision-making roles that holistic constitutionalist proposals invariably entail -

\footnotetext{
${ }^{29}$ See also the discussion in E. MacDonald \& E. Shamir-Borer, 'Meeting the Challenges of Global Governance: Administrative and Constitutional Approaches', Discussion Draft (2008), at www.iilj.org/courses/documents/MacDonald.Shamir-Borer.92508.pdf.

${ }^{30}$ Habermas, Der gespaltene Westen, n 20 above, 133-142.

31 See, e.g., J. Tully, Strange Multiplicity: Constitutionalism in an Age of Diversity (Cambridge: Cambridge University Press, 1995); C. Mouffe, The Democratic Paradox (New York: Verso, 2000); R. Hirschl, Towards Juristocray: The Origins and Consequences of the New Constitutionalism (Cambridge, Mass.: Harvard University Press, 2004).

${ }^{32}$ For a similar account in the European context, see M. Maduro, 'Europe and the constitution: what if this is as good as it gets?', in J.H.H. Weiler \& M. Wind (eds), European Constitutionalism Beyond the State (Cambridge: Cambridge University Press, 2003) 74.
} 
typically in a quasi-federal form - will hardly be satisfactory; giving any level the final say on an issue of global reach will always appear as problematic. ${ }^{33}$

Finally, the holistic ambition also raises problems of a more pragmatic character. On the one hand, it will always seem somewhat unrealistic in a global political context so far removed from ideal models. But while this might not be problematic in itself - after all, much of modern political theory will have sounded unrealistic, utopian, at its beginnings - it might caution us to distance the constitutionalist project from current reform proposals. For if the gap with reality is too big, attempts at entering discussions about reforms in the here and now will likely lead to a lowering of demands - to the pursuit of a much more limited 'constitutionalism' that, rather than redeeming the promise of the domestic ideal, will legitimise deficient structures. More problematically yet, the attempt at refounding global governance on a grand scale in current political circumstances might easily play into the hands of those actors currently dominating international affairs: in a setting as inegalitarian as that of global politics, efforts at providing a stable framework of rules and institutions - at 'constituting' international society are bound to sanction structures that primarily benefit the powerful. The attempt by some to characterise the UN Charter as a constitution ${ }^{34}$ can be seen as precisely that: using constitutional language here is much more likely to legitimise an institution that reinforces the distribution of power after World War II than to provide inroads for critique sufficient to redeem the promise of political selfgovernment constitutionalism evokes.

\section{THE (LIMITED) AMBITION OF GLOBAL ADMINISTRATIVE LAW}

The holistic ambition of foundational constitutionalism thus sits uneasily with the societal and political circumstances of contemporary global politics; less comprehensive approaches might fare better in this context. Among such approaches are the more circumscribed versions of constitutionalism mentioned above, aiming at a greater legalisation of international politics or a stronger enforcement of human rights against the institutions of global governance, much in the older, power-limiting tradition of domestic constitutionalism. While these fall short of the full promise of the constitutionalist tradition ${ }^{35}$, they certainly have a number of substantive virtues. I cannot analyse those in detail here, but will instead focus on a different project with a limited ambition, that of 'Global Administrative Law' (GAL), and explore to what extent that limited ambition is sustainable and attractive. As I mentioned in the introduction, GAL in this reading

\footnotetext{
33 See N. Krisch, 'The Pluralism of Global Administrative Law' (2006) 17 European Journal of International Law 247.

${ }^{34}$ Fassbender, n 26 above.

35 See text at $\mathrm{n} 23$ above.
} 
is not a direct rival to constitutionalist visions; with its more limited ambition and different aims, it operates on a somewhat distinct plane.

GAL starts from the insight that much of global governance can be understood in administrative terms, as global administration that operates in a 'global administrative space' in which the boundaries between the domestic and international spheres have largely broken down. What it is interested in are the 'mechanisms, principles, practices, and supporting social understandings that promote or otherwise affect the accountability of global administrative bodies' 36 , and it has led to studies of a whole range of institutions and their existing or incipient forms of transparency, participation and review. ${ }^{37}$

Just as the constitutionalist projects sketched above, GAL is concerned with the legitimacy of global governance, but it approaches it from a different angle. It focuses on questions of accountability, on the extent to which a global administrative body 'gives account and another [actor] has the power or authority to impose consequences as a result'. ${ }^{38}$ Accountability is a broad concept, and in the understanding just cited includes both circumscribed mechanisms such as judicial review and broader forms of responsiveness through electoral processes or even peer reputation. ${ }^{39}$ Yet because it denotes a particular relationship between actors, and a particular response to legitimacy claims of particular actors, the concept lends itself to a relatively specific use in the observation and analysis of institutional practices and can therefore to some extent avoid the all-encompassing normative connotations of notions such as 'legitimacy'. ${ }^{40}$

GAL seeks to explore and map existing and emerging accountability practices, and it does so in a framework borrowed from administrative law. Here again, like constitutionalist models, it draws on domestic concepts for the understanding and construction of global structures. However, in GAL this move does not imply the prescriptive assumption that the tools of domestic administrative law ought to be transferred into the institutions of global governance, e.g. by establishing judicial review mechanisms wherever individuals are directly affected or by instituting public participation whenever global administrative bodies are engaged in rule-making. Instead, administrative law serves mainly as an inspiration and contrast: it serves as a framework for

\footnotetext{
36 B. Kingsbury, N. Krisch \& R.B. Stewart, 'The Emergence of Global Administrative Law' (2005) 68:3 Law \& Contemporary Problems 15, 17.

37 See the symposium issues of (2005) 68:3 Law \& Contemporary Problems; (2005) 37:4 NYU Journal of International Law and Politics; (2006) 17:1 European Journal of International Law; the Viterbo GAL seminar series with papers at www.iilj.org/GAL/GALViterbo.asp; and the Working Paper Series and further materials on www.iilj.org/GAL.

${ }^{38}$ Black, n 17 above, 150.

39 R.W. Grant \& R.O. Keohane, 'Accountability and Abuses of Power in World Politics' (2005) 99 American Political Science Review 29; J. Ferejohn, 'Accountability in a Global Context', IILJ Working Paper 2007/5, at http://iilj.org/publications/2007-5Ferejohn.asp. But see also the call for greater specificity in R.B. Stewart, 'Accountability, Participation, and the Problem of Disregard in Global Regulatory Governance', Discussion Draft (2008), at http://iilj.org/courses/documents/2008Colloquium.Session4. Stewart.pdf, 5-37.

40 Legitimacy is of course often used in a sociological sense, but the debates I refer to in this paper are typically concerned with its normative scope.
} 
identifying converging and diverging developments in institutional practice, and it helps us sharpen our sensitivity for the problems and possibilities of establishing accountability mechanisms on the global level. Through reflection on the transferability of domestic concepts, the similarities and dissimilarities in both institutional structures and environmental conditions come into much clearer view. ${ }^{41}$ B.S. Chimni's work on the Codex Alimentarius Commission is a case in point: by studying the costs and benefits of stakeholder participation in its regulatory functions, we gain a more precise idea of the limits of using certain administrative law tools and with it a better sense for the conditions under which such tools may further broader normative goals. ${ }^{42}$ Using domestic administrative law as a background rather than as the basis for prescription also reflects the variations in administrative law structures from country to country. GAL scholarship has largely used the prism of US administrative law but has also drawn on other sources ${ }^{43}$, and the resulting comparative angle also allows a sharper understanding of the differences in background assumptions between administrative law systems. ${ }^{44}$ Thus, turning to administrative law for inspiration is mainly an attempt to expand the intellectual and practical resources for thinking about global governance, for bringing out similarities and differences, rather than for particular, transferable prescriptions. ${ }^{45}$

Yet GAL's ambition is more limited than that of constitutionalist projects in a third - and probably even more consequential - way. Apart from its more analytical and systematising aspects, GAL has a strong normative component, but its normative ambition operates on a (relatively) small scale. It does not aim at a full account of the conditions under which global governance, or global administration, would be legitimate or justified but instead aims at elucidating the respective normative values and presuppositions of particular institutional alternatives. ${ }^{46}$ It thus seeks to bracket some of the more intractable issues such as the question of how to ensure democracy on a global scale, and to work instead within a given institutional and social environment, accepting (for the time being) the constraints this environment imposes. For example, in their work on the Basel Committee on Banking Supervision Michael Barr and Geoffrey Miller inquire into the benefits of the recent steps towards stronger participation in the Committee's regulatory process and how it has empowered certain domestic actors, thereby moving it closer to domestic representative institutions and more generally to

\footnotetext{
${ }^{41}$ See, e.g., R.B. Stewart, 'U.S. Administrative Law: A Model for Global Administrative Law?' (2005) 68:3 Law \& Contemporary Problems 63.

42 B.S. Chimni, 'Co-Option and Resistance: Two Faces of Global Administrative Law' (2005) 37 NYU Journal of International Law and Politics 799.

${ }_{43}$ Apart from the symposia, n 37 above, see especially the materials on the workshops in Buenos Aires, New Delhi and Cape Town as well as the Viterbo seminar series, all on www.iilj.org/GAL. See also the symposium in (2008) 9:11 German Law Journal and C. Möllers, A. Vosskuhle \& C. Walter (eds), Internationales Verwaltungsrecht (Tübingen: Mohr Siebeck, 2007).

${ }^{44}$ See, e.g., the comparison in Stewart, n 39 above, 37-56; and the critical analysis in C. Harlow, 'Global Administrative Law: The Quest for Principles and Values' (2006) 17 European Journal of International Law 187.

${ }^{45}$ For an example of an approach stressing differences, see Krisch, $\mathrm{n} 33$ above.

46 Kingsbury, Krisch \& Stewart, n 36 above, 42-51.
} 
domestic ideas of inclusiveness in the process. Likewise, they highlight the continuing limits of effective participation for particular types of domestic groups as well as, more generally, for developing countries. ${ }^{47}$ They do not situate this analysis in a broader theory of global democracy or a full account of what would make an institution like the Basel Committee legitimate; instead they can be seen to operate on a narrower normative basis, assuming that the absence of certain forms of participation would be problematic for a host of different normative theories if they were to be worked out fully. Richard Stewart has explicitly adopted such an approach in his recent work, operating on the assumption of an existing 'working consensus' - rather than a comprehensive theory - on the undesirability of disregard for certain actors in decision-making.48 A similar approach is characteristic for studies that primarily deal with rights-based mechanisms: for example, Mark Pallis's account of UNHCR's accountability to the individuals affected by its refugee status determinations is not concerned with the broader conditions of UNHCR's legitimacy; it focuses only on the more specific, rightsbased elaboration of a procedural minimum standard the violation of which would be problematic whatever broader theories of legitimacy require beyond it. ${ }^{49}$

With this relatively narrow normative focus, the GAL approach resembles the early steps of continental European administrative law systems in the $19^{\text {th }}$ century, most of which developed in a normatively largely unsatisfactory - usually monarchical, often authoritarian - environment and limited itself to advances on specific, circumscribed normative fronts: protecting rights or ensuring legality in order to ensure at least a minimum degree of predictability and consistency. .50 This type of approach does not exclude broader democratic theorising; in fact, explorations of alternatives to election-centered democracy and their potential for realisation on the global level form part of the GAL project ${ }^{51}$, as do inquiries into the democratic limitations of the participatory agenda that underlies many institutional developments in global regulatory rule-making. ${ }^{52}$ But the project of developing a global administrative law does not depend on the result of those explorations. It is a project with a partial, not a comprehensive aspiration and seeks an independent existence both as an analytical project and as a normative one, albeit on narrower (and potentially less contested) grounds.

\footnotetext{
47 Barr \& Miller, n 6 above.

48 Stewart, n 39 above, 11-13.

49 M. Pallis, 'The Operation of UNHCR's Accountability Mechanisms' (2005) 37 NYU Journal of International Law and Politics 869.

50 At a later stage, they also served to ensure executive compliance with parliamentary legislation. See, e.g., on Germany M. Stolleis, Geschichte des öffentlichen Rechts in Deutschland, vol. 2 (München: Beck, 1992) 240243, 381-384. See also D. Dyzenhaus, 'Accountability and the Concept of (Global) Administrative Law', IILJ Working Paper 2008/7, at http://www.iilj.org/publications/2008-7Dyzenhaus.asp, 13-24, on the independent value of legality.

51 E.g., J. Cohen \& C.F. Sabel, 'Global Democracy?’ (2005) 37 NYU Journal of International Law and Politics 763; Macdonald \& Macdonald, n 18 above; Ferejohn, n 39 above.

52 E.g., Harlow, n 44 above; M. Shapiro, "Deliberative”, "Independent" Technocracy v. Democratic Politics: Will the Globe Echo the E.U.?’ (2005) 68:3 Law \& Contemporary Problems 341.
} 


\section{THE LIMITATIONS OF THE LIMITED AMBITION}

Just how limited the ambition of GAL can and should be must remain open to question. Bracketing broader normative and institutional (i.e. 'constitutional') questions creates significant problems: disentangling the two sets of issues will often prove impossible or undesirable, not least because it might conceal or distract from the most pressing concerns about practices of global governance.

Disentangling administrative from constitutional issues is usually already difficult on a practical level. In the early stages of the evolution of administrative law in Europe, the separate pursuit of administrative law often appeared artificial but it was largely inevitable: the monarchical, authoritarian constitutional structures in which it was embedded seemed too resistant to change. ${ }^{53}$ Today, in domestic settings, administrative and constitutional law are typically closely connected in both practice and scholarship, even if the extent of this connection differs from country to country - in the US, the two operate at a certain distance, while in Germany, for example, such distance seems to have largely disappeared. ${ }^{54}$ In the global context, a separation appears easiest when it comes to rights-based mechanisms, such as judicial or quasi-judicial review or due process, as rights may provide a grounding for them that is independent from broader contextual or consequentialist considerations. 55 The problems are more obvious when it comes to questions of transparency and participation in rule-making. For example, how to interpret and assess the participation of developing countries in the regulatory procedure of the Basel Committee largely depends on the composition of the Committee and broader issues of its control; if developing countries had an effective voice within the Committee (and in its creation and design), they might not need procedural participation in the same way to make their concerns heard. ${ }^{56}$ Regulatory procedure and constitutional setup are thus, to some extent, interchangeable forms of engagement, and looking at one without the other is impossible. The challenge of disentanglement becomes ever greater if one considers the impact of the broader institutional context. To take again the Basel Committee's example, the weight of the Committee's regulatory efforts largely depends on its linkages with other institutions, such as the Financial Stability Forum and the International Monetary Fund. ${ }^{57}$ As Basel standards are reinforced and implemented in these other sites, the freedom of states to ignore them becomes ever more virtual, rendering procedural safeguards ever more important. The adequacy of such safeguards, though, cannot be assessed without taking into

\footnotetext{
53 See Stolleis, n 50 above.

54 On Germany, see Schmidt-Assmann, n 16 above, 10-12.

55 The discussion of UN sanctions in the European courts can be seen as reflecting such an approach; see ECJ, Judgment of 3 September 2008, C-402/05 P and C-415/05 P, Kadi \& Al-Barakaat vs Council of the European Union.

56 Cf. Barr \& Miller, n 6 above.

57 See M. de Bellis, 'Global Standards for Domestic Financial Regulations: Concourse, Competition and Mutual Reinforcement between Different Types of Global Administration' (2006) 6:3 Global Jurist Advances no. 6, at www.bepress.com/gj/advances/vol6/iss3/art6.
} 
account the bigger picture of the overall regime complex, i.e. the different institutions involved, their authority, composition, procedures and control mechanisms, and the formal and factual links between them. Disentangling the 'administrative' from the 'constitutional' then looks increasingly difficult.

Such disentanglement also raises significant normative problems. John Ferejohn has recently emphasised the imbalance between legal and political accountability mechanisms in global governance when compared with domestic administrative structures. ${ }^{58}$ In domestic settings, tools such as judicial review, the requirement of giving reasons or public participation in rule-making are embedded in a broader structure in which the public can exchange its rulers at will, largely arbitrarily - in fact, insofar as judicial review is meant to enforce parliamentary statutes, it acts as a 'transmission belt' for democracy's arbitrary choices..$^{59}$ In the global context, such political accountability is largely lacking, and this may not only be a problem in itself but may also alter our interpretation of the more widespread (and more easily established) legal accountability mechanisms. A notice-andcomment procedure without an electoral, parliamentary yardstick may more easily be skewed in favour of particular interests, and a judicial review mechanism that acts as a transmission belt for non-democratically created law also plays quite a different role than its domestic model, even if it succeeds in furthering legal certainty and ensuring a degree of consistency in decision-making. ${ }^{0}$ More broadly, the lack of a democratic, parliamentary 'anchor' shifts the load of including the public in decision-making to administrative procedures alone and might thus overburden them. ${ }^{61}$ And, as Carol Harlow has observed, the imbalanced growth of legal, judicial accountability mechanisms may lead to a 'juridification' of global governance, narrowing further the space for democratic political engagement. ${ }^{62}$ This suggests a potential trade-off between democracy and the rule of law in the shaping of GAL. It may also indicate a certain liberal, perhaps even libertarian bias in the attempt at bracketing broader questions of order in global governance. Focusing on the accountability (and thus largely on constraints) of existing institutions may overemphasise the threat these institutions pose at the expense of more positive, liberal or republican visions that see them as forms and fora for realising self-government or non-domination.

These difficulties also suggest a particular problem associated with the concept of accountability at the centre of the GAL project. In a common interpretation, accountability is understood to include solely ex-post checks to decision-making ${ }^{63}$, but insofar as prior participation and later review fulfill similar functions, focusing on those ex-post checks may miss a significant part of the picture and may lead to distorted normative assessments. Yet if one broadens the

58 Ferejohn, n 39 above.

59 On the role and limitations of the 'transmission belt' model in the US context, see R.B. Stewart, 'The Reformation of American Administrative Law' (1975) 88 Harvard Law Review 1667.

${ }^{60} \mathrm{On}$ the independent value of the latter Dyzenhaus, $\mathrm{n} 50$ above.

${ }^{61}$ Kingsbury, Krisch \& Stewart, n 36 above, 48-50.

62 Harlow, n 44 above, 211-214.

${ }^{63}$ Grant \& Keohane, n 39 above, 30. 
understanding of the concept, as much of the GAL literature has done64, it becomes increasingly difficult to delineate its boundaries. Such a move does not necessarily affect analytical clarity: accountability continues to denote the particular relational dimension between a governance actor and those communities with legitimacy claims on it. ${ }^{65}$ On a normative level, though, the situation is more difficult. Mechanisms of accountability, however defined, are part of a broader interplay of elements of control or influence which may be seen as standing in a zero-sum relationship: if one actor gains greater influence over decision-making, another one loses some of hers. ${ }^{66}$ In this picture, institutions of global governance do not have an accountability "deficit"; they may only be accountable to the wrong accountability holders. ${ }^{67}$ Yet if we cannot assess the adequacy of any mechanism of accountability independently of all other forms of influence in an institution and of a broader normative theory of who ought to control the institution, the prospect of disentangling the 'administrative' from the 'constitutional' becomes ever dimmer.

\section{LEGITIMISING ADMINISTRATIVE STEERING?}

If fully disentangling the 'administrative' from the 'constitutional' is thus not an attractive - or even feasible - option, the limited ambition of GAL can be maintained only by a deliberate narrowness of focus and provisionality of claims. Both analytically and normatively, GAL may then focus on global accountability mechanisms of an administrative-law style but retain awareness of the institutional context in which those mechanisms are embedded and the broader normative questions they raise. GAL inquiries might stop short of addressing those latter issues directly, or at least might not provide answers or prescriptions for them, but keeping them present will help situate the analysis and assessment of the practices it chooses to concentrate on. For example, when analysing the rule-making processes within the OECD, a GAL approach will need to explicate the context in which the institution as a whole is embedded - it may not develop an answer to what the place of the OECD in the global institutional architecture should ultimately be (and indeed whether it should have any) as this would require the form of comprehensive analysis it has chosen to refrain from, but awareness of the broader context will emphasise the relative nature of whatever claims it can make about narrower procedural issues. In the absence of a comprehensive theory, GAL may not be able to make ultimate claims about how the emergence of broader participation rights in OECD rule-making can be compared to

\footnotetext{
${ }^{64}$ See Kingsbury, Krisch \& Stewart, n 36 above.

${ }^{65}$ See text at $\mathrm{n} 17$ above.

${ }^{66}$ See Black, n 17 above, 153.

67 R.O. Keohane, 'Global Governance and Democratic Accountability', in D. Held \& M. KoenigArchibugi (eds), Taming Globalization: Frontiers of Governance (Oxford: Polity, 2003) 130, 145; Krisch, n 33 above, 249-251.
} 
domestic administrative-law analogues or assessed normatively. But GAL can study the process leading up to it, the effects of it and the politics around it, and it may also interpret and assess it in the light of alternative imaginations of the broader order. Any such effort will then be relative and provisional - it will depend on assumptions about elements of a broader theory, and these assumptions need to remain explicit. In this way, we can reconstruct the assertion that GAL seeks to 'bracket' some of the broader issues, such as a theory of global democracy ${ }^{68}$, as an expression of a particular kind of limited ambition: an ambition to come up with relative, provisional conclusions on the interpretation and assessment of a selected range of phenomena. In this sense, GAL is a selfconsciously 'modest' project.

However, even if such a denotation is attractive, the connotations of the project may be more problematic, for it might suggest a degree of legitimacy of a structure that in fact is largely illegitimate. Despite all protestations to the contrary, critics might say, GAL with its use of terms such as law and administration evokes analogies to domestic institutions that are mostly misplaced, and with its focus on accountability it conceals and distracts from more fundamental problems - such as those of democracy - in the global realm. ${ }^{69}$ This is, of course, a serious challenge. Even if one should take care not to overdraw the contrast with the domestic sphere where much administrative action today is also far removed from democratic practices, global governance is particularly problematic in this respect. Its links with domestic democracy are weak, its decentered processes of decisionmaking resist the application of the classical instruments that connect administration with electoral or public deliberative processes, and anything resembling a public sphere is missing on the global level. In this situation, the pursuit of the partial, modest agenda of GAL might indeed seem blind to the true challenges, perhaps actively distracting from them, and a broader approach might seem called for. Yet such a broader approach would likely be beset by some of the same difficulties we have identified above in global constitutionalism's comprehensive ambition; in particular, the distance between current institutional and social conditions and any meaningful conception of democracy is likely to entail either an apologetic downgrading of democratic demands or the utopian insistence on high standards devoid of a chance of realisation. Then, again, a more circumscribed project may be more attractive, as long as its goals and limitations are kept explicit.

Yet there are other, potentially more consequential objections to GAL's approach to global governance. Because it invokes the vocabulary of law, it might - as Alexander Somek points out - create idealisations that "distort our perception of administrative realities" and present as a practice of law what in fact is driven by

68 Kingsbury, Krisch \& Stewart, n 36 above, 51.

69 This risk is highlighted in S. Marks, 'Naming Global Administrative Law' (2005) 37 NYU Journal of International Law and Politics 995. 
administrative rationality. ${ }^{70}$ In Somek's view, global governance is characterised by the absence of legal relationships: actors are not engaged by rules in a merely external fashion but are made to internalise the project of global regulators, to share the teleology of the rules rather than just obey them. This observation is probably true, at least in part, for the public actors (international institutions, states, regulators) that take part in global governance; for a regulatory regime to work in the absence of enforcement capacities, it depends on a positive attitude of participants and subjects. This does not necessarily imply a loss of freedom as compared to the "legal" relationship, as Somek implies: being engaged by the rules because one co-authors them, as happens in regulatory networks, may well be a gain in self-government. ${ }^{71}$ Yet it might indeed signal the absence of "law" and consequently call into question the appropriateness of naming "global administrative law" what might perhaps better be called "global administration".

Such a conclusion would, however, rely on an overdrawn dichotomy between legal and administrative (or managerial) rationality: rather than merely opposed modes of action, the two are better seen as poles on a continuum. Domestic administration is not characterised by a legal relationship alone; administrative law is caught in an uneasy tension between those different rationalities already in the national context. ${ }^{72}$ In global administration, the tension plays out somewhat differently, but the difference is merely gradual: we may situate global governance on a different point on the continuum, further towards administrative rationality, but this does not mean law is absent - it may simply be less extensive and consequential. In fact, GAL points precisely to the inroads into the managerial that law, rules and normative expectations have made, mostly in procedural terms, through legality control, participation and transparency. Take, for example, the World Bank Inspection Panel, which - despite all its shortcomings institutionalises respect for (internal) rules even when they lead to a clash with expediency in a given case. And not only has the Panel had an effect on the operation of the World Bank itself, it has also helped create a broader expectation that development banks be subject to review mechanisms, leading to emulation in a number of other institutional contexts. ${ }^{73}$ This does not displace administrative rationality in any of the banks concerned, but it conditions it to some extent - just as administrative law does in the domestic context.

However, it may still be asked - as David Dyzenhaus has recently done ${ }^{74}-$ whether there is any particular role of "law" as such in GAL, given that much of

\footnotetext{
70 A. Somek, 'Administration Without Sovereignty' University of Iowa Legal Studies Research Paper 09-04, at http://ssrn.com/abstract=1333282.

${ }^{71}$ By contrast, those actors external to the rule-making process, forced to follow the rules because of the costs of non-compliance, may be said to be in a legal relationship (subject to rules they are expected merely to comply with) but are hardly any freer. Think only of states not members of the Basel Committee or the Financial Action Task Force but still subject to its regulation.

72 See Dyzenhaus, n 50 above, 13-16; Somek, n 70 above, 15-16.

73 See D. Bradlow, 'Private Complainants and International Organizations: A Comparative Study of the Independent Inspection Mechanisms in International Financial Institutions' (2005) 36 Georgetown Journal of International Law 403.

74 Dyzenhaus, n 50 above.
} 
the practices it is concerned with have an ambiguous or clearly informal status. There is, of course, a significant amount of "hard" law in the foundational documents of international institutions as well as in the domestic or regional law that affects global regulatory regimes; often we can indeed observe an oversupply of legal rules, with undecided hierarchies and a need for conflict resolution among them. ${ }^{75}$ Moreover, many global rules turn into formal law once they are implemented by domestic (legislative or administrative) actors. Still, much of global regulatory governance takes the form of explicitly non-binding rules, and many of the procedural developments GAL describes are not the result of binding rules either. Yet they often share many characteristics of law and many of the elements of its particular internal morality. ${ }^{76}$ For example, World Bank policies on issues such as resettlement or indigenous peoples are general, public and relatively clear rules that are not easily changed and that the Bank's administrative action has to be congruent with; moreover, the Inspection Panel, among other avenues, offers a way to police that congruence. This may not be conclusive - the Panel's findings can eventually be set aside by the Bank. But ignoring them comes at a significant cost, and even if the Inspection Panel may initially have been set up, in part, to further administrative efficiency, the dynamic it has created means it can certainly no longer be simply reduced to such considerations.

As in other institutions, this supports Dyzenhaus's observation that rule by law often (though by no means always) fosters the rule of law. ${ }^{77}$ This does not imply that all those rules and practices should be awarded the status of formal law, binding on its subjects and on a par with norms of international or constitutional law - this would indeed often contradict the understanding of the participants and may often not be desirable either. ${ }^{78}$ But not all law needs to be the same; some rules might share certain but not all characteristics with others; and different legal orders may operate in different spheres and be only loosely coupled with one another. And it will certainly be fruitful, as Dyzenhaus urges us, to investigate further into the extent to which the rules and practices of GAL do indeed bear the characteristics of law and are thus set apart from mere administrative, managerial rationalities; this should also force us to address the question of which concept of law is adequate to conceptualising global normative practices. The tension between "law" and "administration" in global governance will not disappear, but rather than obscuring it, GAL - like its domestic counterpart - can be seen as making it explicit: as defining it as a challenge, as a subject of investigation, and thus drawing it out into the open.

\footnotetext{
75 Krisch, n 33 above.

${ }^{76}$ See the discussion in Dyzenhaus, n 50 above, 21-24.

77 ibid 22.

78 See also Kingsbury, Krisch \& Stewart, n 36 above, 29-31; N. Krisch \& B. Kingsbury, 'Introduction: Global Governance and Global Administrative Law in the International Legal Order' (2006) 17 European Journal of International Law 1, 12. However, Benedict Kingsbury is more openly sympathetic to reconceptualising many of the practices as part of a new ius gentium: Kingsbury, 'Omnilateralism and Partial International Communities: Contributions of the Emerging Global Administrative Law' (2005) 104 Journal of International Law and Diplomacy 98, 110-115.
} 


\section{CONCLUSION}

Many certainties have disappeared in the globalised world, among them the longestablished separation between the domestic and international spheres in politics and law. The gaps left by that disappearance are wide, and the need to fill them is urgent: too fragile is the legitimacy of the global and transnational governance institutions that have assumed many of the functions domestic governments used to perform. As I have suggested in this article, though, the most obvious steps to fill the gap are highly problematic. Attempts at radically reshaping, indeed refounding, the global political structure by following a form of "global constitutionalism" may exert a strong appeal in the current, very unsatisfactory situation, but they are unlikely to suit the extremely diverse, contested and rapidly changing character of global society. Moreover, seeking to establish a coherent, well-ordered structure of political institutions in the global realm today may not only exceed our abilities to understand the parameters in which it would have to operate, or predict how these parameters will develop in the future; it might also play into the hands of those actors that dominate current global politics and are thus likely to shape any new institutional order.

Instead of such large-scale, "constitutionalist" endeavours we are thus better advised to pursue projects of a more limited ambition, and I have focused here on one of these - global administrative law. GAL has a narrower ambit than constitutionalist approaches, in that it focuses on accountability mechanisms in global regulatory governance; it is less prescriptive about the uses of domestic models; and it operates on a narrower normative basis, bracketing to some extent the question which fully worked-out, comprehensive theories can ultimately ground global and transnational institutions. This more limited ambition creates serious problems, not least because questions of overall structure can hardly be disentangled - practically and normatively - from those of concrete accountability mechanisms. Moreover, by bracketing the broader questions GAL may be seen to distract from them, or even to legitimise illegitimate structures by elevating them to the level of "law". This can be avoided by being explicit about GAL's limited aims and only provisional claims, but it is a very fine line to walk.

To the more philosophically minded, limiting one's ambitions in this way may appear insufficient; they will insist on theorising on a larger scale, with comprehensive aims. This is intellectually understandable: bracketing central issues may simply appear as shying away from the most difficult questions. And even as a matter of institutional design, confining ourselves to partial, limited solutions may make us lose sight of the overall edifice, leading to an incoherent whole that we might eventually have to rebuild altogether - it might create a "monstrous" structure, similar to the one Pufendorf deplored (and sought to overcome) in the Holy Roman Empire. ${ }^{79}$ Yet just as remaking the Empire's institutions in a

\footnotetext{
${ }^{79}$ Severinus de Monzambano (Samuel Pufendorf), De statu imperii Germanici (1667) ch. VI, $\$ 9$.
} 
coherent fashion found its limits in the political and social conditions of early modernity, thinking about the design of global governance cannot succeed without consideration of the complex shape of global politics and society today, of our incomplete understanding it and our limited ability to effect change. In the "twilight" in which we find ourselves today proceeding in small steps, with limited ambition, may be the only sensible option. In the case of GAL, it may be one that allows us to sharpen our focus and begin to answer crucial questions of global governance without leaping to grand designs borrowed from dissimilar contexts and likely at odds with the fluid and diverse character of the postnational polity. 